\title{
UV-VIS spectrophotometric determination of magnesium after complexing with 8-hydroxy quinoline in sodium dodecyl sulphate micellar medium
}

\author{
Cemalettin UYAN ${ }^{1 *}$ (D), Ersin YILMAZ ${ }^{1}$ (iD) \\ ${ }^{1}$ Sivas Cumhuriyet University, Faculty of Science, Department of Chemistry, Sivas /TURKEY
}

\begin{abstract}
In this study, an alternatifive UV-VIS spectrophotometric method for determination of magnesium was proposed. The method is based on complexation with 8-hydoxyquinoline (oxin) in sodium dodecyl sulphate (SDS) micelle medium, the absorbance of the product was recorded at $390 \mathrm{~nm}$. $\mathrm{pH}$ of the solution, the concentration of ligand and surfactant were critical parameters, which affect the absorbance measurements, and optimised. The molar absorptivitiy coefficient is $5 \times 10^{2} \mathrm{Lmol}^{-1} \mathrm{~cm}^{-1}$, the Sandell's sensitivity is $0,052 \mu \mathrm{gcm}^{-2}$, detection limit is $0,3 \mathrm{mgL}^{-1}$, quantification limit is $1,1 \mathrm{mgL}^{-1}$ and linear working range is $2-8$ $\mathrm{mgL}^{-1}$ at $\mathrm{pH} 12$ and $390 \mathrm{~nm}$. The proposed method was applied for determination of magnesium to some drug and mineral water samples, nearly good accuracy and reproducible volues were obtained percent as recovery and relative standart deviation.
\end{abstract}

\author{
Article info \\ History: \\ Received:08.10.2019 \\ Accepted:05.06.2020 \\ Keywords: \\ Magnesium analysis, \\ UV-VIS \\ spectrophotometric \\ method, \\ 8-hydoxyquinoline, \\ Sodium dodecyl \\ sulphate, \\ Micellar medium.
}

\section{Introduction}

Magnesium determination areas are great variety. These areas can be classified as water, industry, clinic, foods. Magnesium determinations were made by gravimetric, volumetric, atomic spectrophotometric, UV-VIS spectrophotometric, fluorimetric, electroanalytical and ion chromatographic method. Atomic absorption spectrophotometric (AAS) pathway is the best method for metal ions determination. However, because this instrument is expensive, not every routine analysis is available. The UV-VIS spectrophotometric methods are the most common. The conventional UV-VIS spectrophotometric determination of metal ions is based on the complexation of the metal ion with a ligand. UV-VIS spectrophotometric methods are divided into three in terms of the micro environment of the species where the signal is measured. These are: 1) Aqueous media 2) Organic solvent media (with liquid-liquid extraction) 3) Micellar media methods. Information about these studies were given in Table 1, Table 2 and Table 3.

While the direct aqueous medium method is more advantageous, the liquid-liquid extraction method has been developed in cases where the metal complex does not dissolve in water or good peaks are obtained. One way for the same situations is to measure the signal in micelle. The micelle medium of a surfactant whose suitability is determined experimentally leads to improvement. The reason for this improvement can be explained as follows. The analyte species or its derivation is attached by micelle (held by the micelle), which changes the spectroscopic property of the different surrounding species by affecting the orbital energy levels, resulting in a better peak. The micelle media methods also have the following advantages: 1) Environmentalist; surfactants undergo biological degradation very quickly compared to organic solvents. 2) Cost of analysis is lower; in one assay, the surfactants are used in very small amounts relative to organic solvents. 3) The method is shorter and easier since no separation is required [1].

In this study, an alternative method for determination of magnesium in micelle medium is proposed. For mycelium, In this study, SDS as a surfactant and oxin as a ligand are used for the determination of $\mathrm{Mg}$. In the literature, no studies have found these three together. With the realization of this study, we will present an alternative method of magnesium determination which can meet the demands of institutions that do not have AAS device because they do not have budgets. 
Table 1. UV-VIS Spectrophotometric determination of magnesium in aqueous medium

\begin{tabular}{|c|c|c|c|c|c|c|}
\hline Ligant & $\mathrm{pH}$ & $\begin{array}{l}\lambda_{\max } \\
(\mathrm{nm})\end{array}$ & $\begin{array}{l}\text { Dedection } \\
\text { limit } \\
\left(\mathrm{mg} \mathrm{L}^{-1}\right)\end{array}$ & $\begin{array}{c}\varepsilon^{\times 10^{-3}} \\
\mathrm{M}^{-1} \mathrm{~cm}^{-1}\end{array}$ & $\begin{array}{c}\text { Linear } \\
\text { working } \\
\text { range } \\
\left(\mathrm{mg} \mathrm{L}^{-1}\right) \\
\end{array}$ & References \\
\hline Eriochrom Black T & $9.5-11.7$ & 630 & - & - & - & [2] \\
\hline $\begin{array}{l}\text { Chlorophospho-nazo } \\
\text { III }\end{array}$ & 7 & 699 & - & - & - & [3] \\
\hline Chromotrope 2R & 10.8 & 570 & - & - & - & [4] \\
\hline Titan Yellow* & $>12$ & 545 & - & 2.8 & - & {$[5]$} \\
\hline $\begin{array}{l}\text { Acid Chrome Black } \\
\text { Special* }\end{array}$ & 10 & 540 & - & 33 & - & {$[5]$} \\
\hline Calmagite & alkaline & 520 & - & - & $0,0-36$ & {$[6]$} \\
\hline $\begin{array}{l}\text { 1,8- dihydroxy- } \\
\text { anthraquinone }\end{array}$ & - & 510 & - & - & $0.25-2.00$ & [7] \\
\hline Xylidyl Blue-1 & alkaline & 524 & - & 22 & $0-4$ & {$[8]$} \\
\hline Terpiridine & 3 & 668 & - & - & - & [9] \\
\hline Furfurin & 9.5 & 540 & 0,075 & 9,2 & $0.8-4.3$ & [10] \\
\hline $\mathrm{CPC}$ & 10.5 & 570 & 0.24 & - & $0-20$ & [11] \\
\hline Acid Chrome Blue K & - & 540 & - & 9.3 & $0-2$ & [12] \\
\hline Bromopyrogallo Red & 9.4 & $\begin{array}{c}\text { RS- } \\
\mathrm{CWT}^{* *}\end{array}$ & - & - & $0.2-3,2$ & [13] \\
\hline
\end{tabular}

* photometric

** Continuous wavelenght transforms

Table 2. UV-VIS spectrophotometric determination of magnesium with liquid-liquid extraction

\begin{tabular}{|c|c|c|c|c|c|c|c|}
\hline Ligant & Solvent & $\mathrm{pH}$ & $\begin{array}{c}\lambda_{\max } \\
(\mathrm{nm})\end{array}$ & $\begin{array}{c}\text { Dedectio } \\
\mathrm{n} \mathrm{limit} \\
\left(\mathrm{mgL}^{-1}\right)\end{array}$ & $\begin{array}{c}\varepsilon \times 10^{-3} \\
\mathrm{M}^{-1} \mathrm{~cm}^{-1}\end{array}$ & $\begin{array}{c}\text { Linear } \\
\text { working } \\
\text { range } \\
\left.\mathrm{mgL}^{-1}\right)\end{array}$ & References \\
\hline 8-hydoxyquinoline* & Cloroform & $11.2-11.3$ & 380 & - & 5.6 & - & {$[5]$} \\
\hline PTTHA & Cloroform & 9.5 & 590 & - & 2.8 & - & {$[14]$} \\
\hline
\end{tabular}

* Photometric 
Table 3. UV-VIS spectrophotometric determination of magnesium in micellar medium

\begin{tabular}{|l|l|c|c|c|c|c|c|}
\hline Ligant & Surfactan & $\mathrm{pH}$ & $\begin{array}{c}\lambda_{\max } \\
(\mathrm{nm})\end{array}$ & $\begin{array}{c}\text { Dedection } \\
\text { limit } \\
\left(\mathrm{mgL}^{-1}\right)\end{array}$ & $\begin{array}{c}\text { Linear } \\
\mathrm{M}^{-1} \mathrm{~cm}\end{array}$ & $\begin{array}{c}\text { working } \\
\text { range } \\
\left(\mathrm{mgL}^{-1}\right)\end{array}$ & References \\
\hline Calmagite & Empigen BB & 11.5 & 655 & - & - & - & {$[15]$} \\
\hline $\begin{array}{l}\text { Xylidyl } \\
\text { Blue -1 }\end{array}$ & Brij 35 & alkaline & 505 & - & - & $0.0-48$ & {$[16]$} \\
\hline $\begin{array}{l}\text { Bromopyrogallo } \\
\text { 1 Red }\end{array}$ & Tween 80 & 10 & 570 & 0.03 & - & $0.5-3.5$ & {$[17]$} \\
\hline $\begin{array}{l}\text { Eriochrome } \\
\text { Black T }\end{array}$ & CTAB & 9.5 & 640 & 0.012 & 8.9 & $0.05-1.2$ & {$[18]$} \\
\hline
\end{tabular}

\section{Materials and Methods}

\subsection{Tools and Equipment}

UV-VIS Spectrophotometer: UV-1800 UV-VIS Spectrometer and UNICAM UV-VIS Spectrometer UV 2 pH meter: Adwa AD8000.

\subsection{Reagents}

Solids of all reagents are of analytical purity. The solutions were prepared with double distilled water.

1) $375 \mathrm{ppm}$ Oxin solution (pH 12): $0.0940 \mathrm{~g}$ of solid auxin was removed and transferred to a $250 \mathrm{~mL}$ beaker. It was diluted close to the adjustment line and the $\mathrm{pH}$ was 12. A $250 \mathrm{~mL}$ flask was then transferred to the flask and raised to the volume adjustment line with water. It was observed that the solution exceeding one week after preparation should not be used.

2) Sodiumdodecylsulfate (SDS): $5 \%(\mathrm{w} / \mathrm{v}) .5 .0 \mathrm{~g}$ of SDS solid were dissolved in water and the volume was completed to $100 \mathrm{~mL}$. To use this solution should not exceed a week.
3) $\mathrm{pH} 12$ Glycine Buffer: Firsty, the following two solutions were prepared: $3-1)\left(0.2 \mathrm{M} \mathrm{NH}_{2} \mathrm{CH}_{2} \mathrm{COOH}\right.$ $+0.2 \mathrm{M} \mathrm{NaCl}$ ) solution: $1.5014 \mathrm{~g}$ of glycocol and $1.1688 \mathrm{~g}$ of $\mathrm{NaCl}$ were dissolved in a small amount of water in the same beaker and $100 \mathrm{~mL}$ of flask. the volume to $100 \mathrm{~mL}$. 3-2) $0.2 \mathrm{M} \mathrm{NaOH}$ solution: $0.8 \mathrm{~g}$ of sodium hydroxide was dissolved in some pure water and then made up to $100 \mathrm{~mL}$ with volume of water. $54.6 \mathrm{~mL}$ of the second solution, $45.6 \mathrm{~mL}$ of the first solution were taken and mixed [4]. Alternatively, at various concentrations $\mathrm{NaOH}$ is added drop by drop to the first solution (prior to completion to $100 \mathrm{~mL}$ ) until the $\mathrm{pH}$ is adjusted to $\mathrm{pH} 12.0$ at a well-adjusted $\mathrm{pH}$ meter, then added to $100 \mathrm{~mL}$ with water.

4) $1000 \mathrm{mgL}^{-1} \mathrm{Mg}$ (II) standard: $10,1411 \mathrm{~g}\left(\mathrm{MgSO}_{4}\right.$ $27 \mathrm{H}_{2} \mathrm{O}$ solid was weighed and dissolved in water, was transferred to a $1 \mathrm{~L}$ balloon joje and the volume was completed with water to liter.

5) $100 \mathrm{mgL}^{-1} \mathrm{Mg}$ (II) standard: It was prepared by diluting ten times before the previous one.

\subsection{Recommended Method}

A series of balloon joje of $10 \mathrm{~mL}$ each are collected. These are made in two groups, one for calibration curve and the other for samples. To each of the flasks in both groups were added $4 \mathrm{~mL}$ of oxin $\left(375 \mathrm{mgL}^{-1}\right)$, $1.5 \mathrm{~mL}$ of $\operatorname{SDS}(5 \% \mathrm{w} / \mathrm{v}), 1 \mathrm{~mL}$ of $\mathrm{pH} 12$ glycine buffer, with the following four solution sequences, volumes and concentrations. For calibration, 200 - 400 - 600 - $800 \mu \mathrm{L}$ of $100 \mathrm{mgL}^{-1} \mathrm{Mg}$ (II) is added sequentially and each amount is parallel. $400 \mu \mathrm{L}$ of the prepared sample is added to each of the balloons taken for the sample (at least three) and pre-added to the reagent. The solution levels are completed with double distilled water to the marking line, sealed and mixed. 
Absorbance measurements of the solutions in the flasks at $390 \mathrm{~nm}$ are started without passing over the last addition. Absorbance measurements should be completed in less than 20 minutes, the first reading and the last reading should be between 10 and 15 minutes at most.

\subsection{Preparation of samples}

2.4.1. Preparation of magnesium sulfate ampoule sample $330 \mu \mathrm{L}$ was taken from the original sample and diluted to $1 \mathrm{~L}$.

2.4.2. Preparation of Magnesie Calsinee Saba sample

Some solid powder was transferred to a vessel and left in the etuv at $120^{\circ} \mathrm{C} .0 .600 \mathrm{~g}$ of this was weighed. 25 $\mathrm{mL}$ of $1 \mathrm{M} \mathrm{HNO}_{3}$ was dissolved. $6 \mathrm{M} \mathrm{NaOH}$ was added to make the $\mathrm{pH}$ slightly basic. The solution was transferred to a $100 \mathrm{~mL}$ flask and the volume was completed to the marking line with double distilled water (Solution A). $2000 \mu \mathrm{L}$ of this was transferred to a $50 \mathrm{~mL}$ flask and diluted to this volume (Solution B).

\subsubsection{Preparation of Magnesie Calsinee Saba sample}

One film tablet was taken and weighed. $31 \mathrm{~mL}$ of $1 \mathrm{M}$ $\mathrm{HNO}_{3}$ was added to the beaker and stirred for a long time. Filtered. It was made slightly basic so that the $\mathrm{pH}$ was between 8-9. The volume was made up to $250 \mathrm{~mL}$ with water (Solution A). 6,850 mL $(6.0 \mathrm{~mL}+850 \mu \mathrm{L})$ was taken and diluted to $100 \mathrm{~mL}$ (Solution B).

\subsubsection{Preparation of magvital drug sample}

One bowl was taken and the whole powder was transferred and weighed. Water was added to the beaker and mixed. Waited until the bubbles disappear in the water. To this solution, $\mathrm{pH} 3.4,1 \mathrm{M} \mathrm{HNO}_{3}$ was added dropwise to a $\mathrm{pH}$ of about 2 and heated. $6 \mathrm{M}$ $\mathrm{NaOH}$ was added to make the $\mathrm{pH}$ slightly basic. The volume was completed to $250 \mathrm{~mL}$ (Solution A). 6.850 $\mathrm{mL}(6 \mathrm{~mL}+850 \mu \mathrm{L})$ was taken and diluted to $100 \mathrm{~mL}$ (Solution B).

\subsubsection{Preparation of water samples}

The water sample mineral water was transferred to a beaker after the bottle was opened and waited until the exit of the gas bubbles was completed. The post is the same for both. Filtered. It was then taken up to a certain volume and acidified and heated, then made slightly basic to a $\mathrm{pH}$ of from about 8-9 to the same as that of the $\mathrm{Mg}$ standard. The solution is transferred to a flask which its volume was pre-determined, then is diluted.

\section{Results and Discussion}

\subsection{Effect of SDS micelle on the spectrum of Mg- oxin complex}

Critical micelle concentration $(\mathrm{cmc})$ value of SDS is given as $8.1 \times 10^{-3} \mathrm{M}(0.23 \%$ (w / V) [18]. The volume to be added at least is $0.0162 \mathrm{~mL}$, since the value added here is much larger than this value, the measuring medium will certainly be micelle.

When the spectra of the oxin buffer (glycine pH12) Mg st mixture were taken in one medium without SDS and the other with SDS micelle medium, respectively, Figure 1 and Figure 2 were obtained. As shown in the second figure, an analytical peak was obtained in SDS micelle medium.

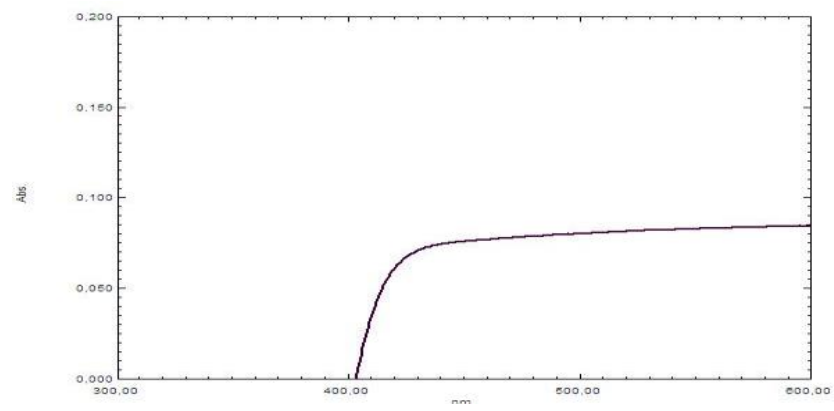

Figure 1. Spectrum of Mg-oxin complex in the absence of surfactant. $10 \mathrm{~mL}$ total volume Reactive additives in: $3 \mathrm{~mL}$ oxin (saturated in pure water), $1 \mathrm{~mL}$ buffer ( $\mathrm{pH} 12)$ and 0.5 mL 100 ppm Mg (II)

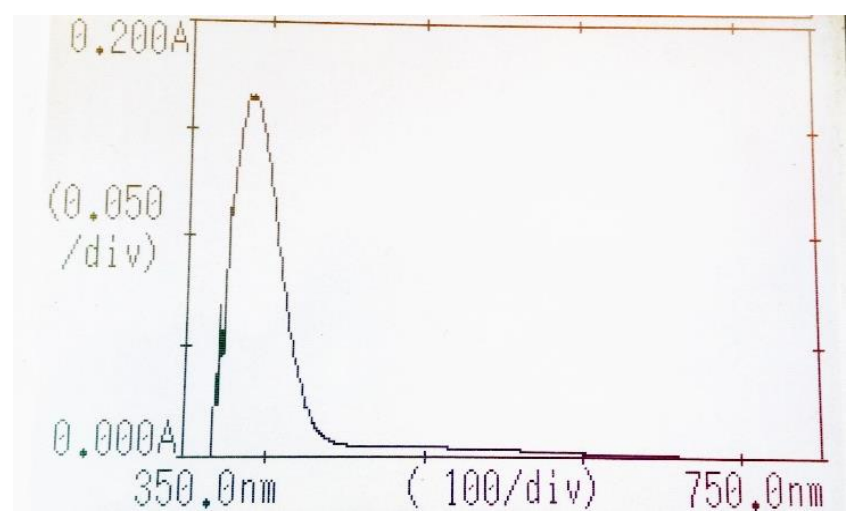

Figure 2. Spectrum of $\mathrm{Mg}$-oxin complex in SDS micelle medium. Media composition: $[$ Oxin $]=150 \mathrm{mgL}^{-1},[\mathrm{SDS}]=$ $0.026 \mathrm{M}\left(0.75 \%(\mathrm{w} / \mathrm{v}), \mathrm{pH}=11.5-12,[\mathrm{Mg}(\mathrm{II})]=8 \mathrm{mgL}^{-1}\right.$

\section{2. pH effect}

To determine the optimum $\mathrm{pH}$, the following was followed: A series of $10 \mathrm{~mL}$ flasks were taken. To each flask $3 \mathrm{~mL}$ of saturated oxin, $2 \mathrm{~mL}$ of SDS (5\% w / v), $1 \mathrm{~mL}$ of buffer (pH 2, 3, 4, 5, 6, 7, 8, 9, 10, 11, 12), 200 
$\mu \mathrm{L} 100 \mathrm{mgL}^{-1} \mathrm{Mg}$ (II) standard was added. The solution volumes were made up to $10 \mathrm{~mL}$ with double distilled water. Blank solution was taken as reference; this was not prepared for all solutions, but individually prepared at each $\mathrm{pH}$.

The spectra of each solution were taken separately. Peaks were not obtained from solutions of $\mathrm{pH} 2-8$, Turbidity was observed at $\mathrm{pH} 8$. Analytical peaks were obtained from $\mathrm{pH} 9$ and above. Figure 3 was obtained when the absorbances measured at the wavelength peaking at each $\mathrm{pH}$ were plotted against $\mathrm{pH}$. As shown in the graph, the absorbance at $\mathrm{pH} 12$ is maximum. 12 was chosen as the optimum $\mathrm{pH}$.

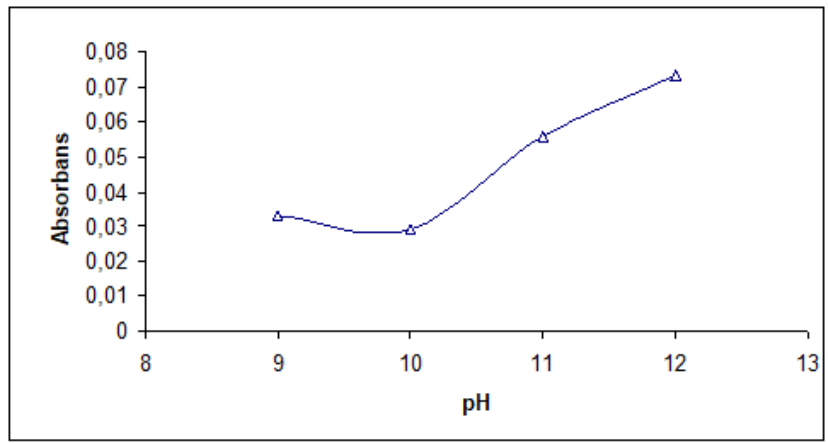

Figure 3. Effect of $\mathrm{pH}$ on absorbance. Media content: Oxin: Saturated diluted (in pure water) 3/10 after addition, SDS: $1 \% \mathrm{w} / \mathrm{v}$ (after addition), The $\mathrm{pH}$ values shown are those of the added buffers (initial), $[\mathrm{Mg}$ (II) $]=2 \mu \mathrm{gL}^{-1}$ (after addition)

\subsection{Effect of oxin concentration on absorbance}

To determine the optimum oxin concentration, the reagents were added with the oxin volume variable and the others constant: The oxin reagent volume was predicted to be $4 \mathrm{~mL}$ before determining the optimum concentration. $1000 \mathrm{ppm}$ oxin $(0.01 \mathrm{M} \mathrm{NaOH})$ solution in different volumes of $0.5,1.0,1.5,2.0 \mathrm{~mL}$ was transferred to the balloons. $3.5-2 \mathrm{~mL}$ of double distilled water was added, each having a total volume of $4 \mathrm{~mL}$. To each was added $2 \mathrm{~mL}$ of $5 \%$ SDS and $1 \mathrm{~mL}$ of buffer (pH12), $200 \mu \mathrm{L}$ of $100 \mathrm{ppm} \mathrm{Mg}$ (II). The solution volumes were completed to $10 \mathrm{~mL}$. Each volume was made in parallel. A different blank solution was used for each oxin concentration. The absorbances of the solutions were measured at peak wavelength. The mean of the parallel ones were taken. Figure 4 was obtained when the absorbance versus oxin volume was plotted.

According to the graph, the $1.5 \mathrm{~mL}$ volume is the optimal volume, which corresponds to a final concentration of $150 \mathrm{ppm}$ after this dilution (completion to $10 \mathrm{~mL}$ ). If the volume of oxin is taken to $4 \mathrm{~mL}$, the initial concentration corresponds to 375 ppm.

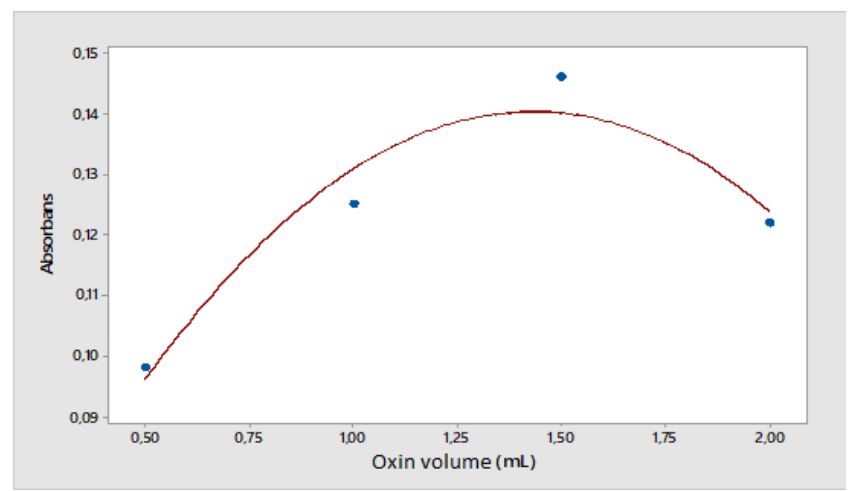

Figure 4. Effect of oxin concentration on absorbance. Solution additives in a volume of $10 \mathrm{~mL}$ : $1000 \mathrm{mgL}^{-1}$ oxin (at $0.01 \mathrm{M} \mathrm{NaOH}$ ) variable, $2 \mathrm{~mL} \operatorname{SDS}(5 \%), 1 \mathrm{~mL}$ buffer (pH12 glycine), $200 \mu \mathrm{L} 100$ ppm Mg (II) standard

\subsection{Effect of SDS concentration on absorbance}

In order to determine the optimum SDS concentration, the reagents were added at this time with the variable SDS volume being variable and the others constant: 4 $\mathrm{mL} 375$ ppm oxin (pH 12), 1-3 mL 5\% SDS in different volumes, $1 \mathrm{~mL}$ pH 12 glycine buffer, $300 \mu \mathrm{L} 100$ ppm $\mathrm{Mg}$ standard was added. The solution volumes were completed to $10 \mathrm{~mL}$. One blank was prepared for all as a reference. Figure 5 was obtained when the absorbance values measured at the peak giving wavelength were plotted against the added SDS volume.

There seems to be much deviation between the absorbances values in the graph. This is because the absorbance axis was scaled at very narrow intervals. In fact, there is not much deviation in absorbance. $1.5 \mathrm{~mL}$ was taken as the appropriate SDS concentration.

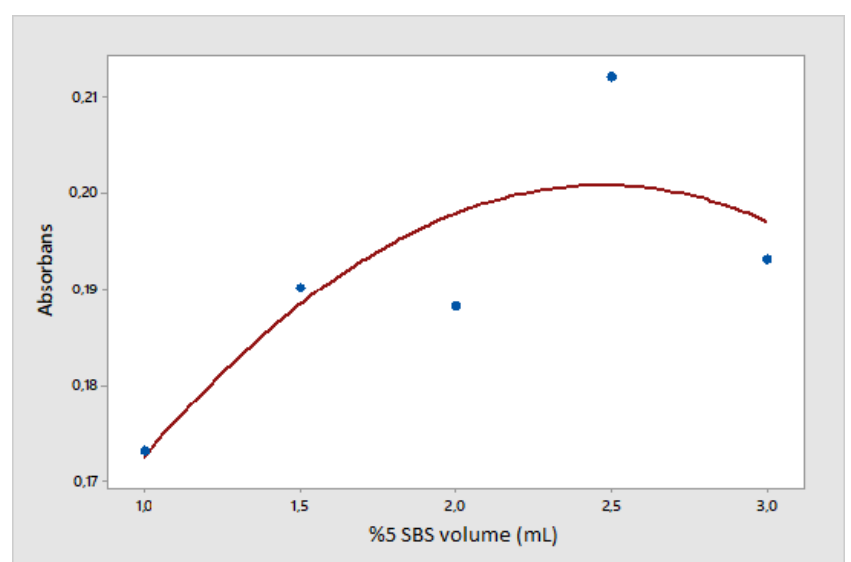

Figure 5. Effect of SDS concentration on absorbance. Additives in a volume of $10 \mathrm{~mL}: 4000 \mu \mathrm{L} 375 \mathrm{mgL}^{-1}$ oxin :, SDS: different, $1000 \mu \mathrm{L}$ Buffer (pH12 glycine), $100 \mathrm{mgL}^{-}$ 1, $300 \mu \mathrm{L}, \mathrm{Mg}$ (II) standard 


\subsection{Optimum wavelength}

The peak wavelength varies according to the $\mathrm{pH}$ of the medium, and the lower the wavelength, the lower the wavelength. The $\mathrm{pH}$ in Figure 3 showing the effect of absorbance on the $\mathrm{pH}$ is not the $\mathrm{pH}$ of the medium, but the $\mathrm{pH}$ of the buffers used before addition. After addition, the $\mathrm{pH}$ drops slightly below that of the added buffer. As the ambient $\mathrm{pH}$ is lower than 12, the peak wavelength shifts from 392 to $365 \mathrm{~nm}$. The amount of shear varies according to the concentration and $\mathrm{pH}$ of oxin used. Oxin has the lowest solubility in pure water and is about $45 \mathrm{mgL}^{-1}$. The saturated auxin solution in pure water is slightly acidic. The solubility of oxin increases at high $\mathrm{pH}$. When saturated oxin (in pure water) is used, the $\mathrm{pH}$ decreases further. In experiments using this solution, peak wavelength was observed below $390 \mathrm{~nm}$ and absorbances were measured accordingly. When the oxin solution was adjusted to a $\mathrm{pH}$ of 12 and had a higher and optimal concentration, it was observed that the decrease in $\mathrm{pH}$ was less than 12 and the peak wavelength was $390 \mathrm{~nm}$ or close. This value corresponding to the optimal $\mathrm{pH}$ as the optimal wavelength was taken.

One way to reduce the $\mathrm{pH}$ drop after buffer addition is to increase the buffer capacity. In subsequent experiments, the buffer components were prepared in such a way that the concentrations of glycine and $\mathrm{NaOH}$ were doubled (the preparation given in Section 2.2 was this).

\subsection{Stability and optimum reading time}

When the balloons were last added, the levels were equalized and the absorbance signals were monitored after closing the mouths, the signals could not remain stable for a long time. As can be seen in Figure 6, in the spectrum band, there was a rise in ground (noise) over time, with higher concentrations. The spectra in the figure were taken approximately $30 \mathrm{~min}$ after the preparation of the solutions and starting at the lowest concentration $\left(2 \mathrm{mgL}^{-1}\right)$. Others were taken at about 510 minute intervals, with a higher concentration later. After 45 minutes, peak $\lambda$ max values also changed and the peak feature disappeared and turbidity occurred in the solution. The cloudiness was not observed in the empty trial solution; this shows us that clouding is not caused by coagulation of micelles.

Ground rise was not seen until the first 20 minutes. It is insignificant for the first 30 minutes. The start of the absorbance measurements of the solutions should not exceed 20 minutes after the final solution component has been added and the levels have been equalized and the mouth closed, the measurement should be completed in 10, maximum 15 minutes.

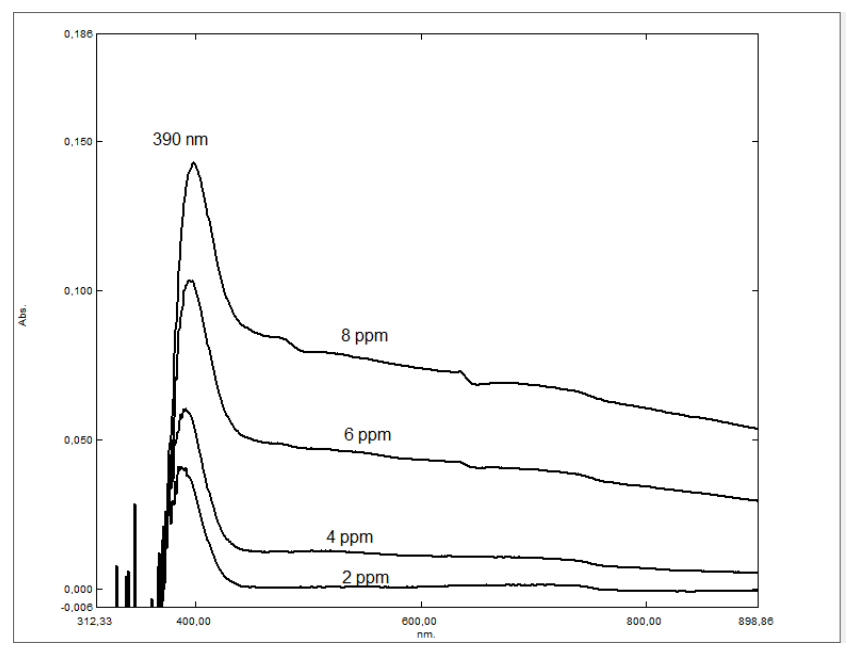

Figure 6. UV-VIS absorption spectrum according to the method and its variation over time. Media composition; [oxin $]=150 \mathrm{mgL}^{-1},[\mathrm{SDS}]=0.026 \mathrm{M}(0.75 \%(\mathrm{w} / \mathrm{v}), \mathrm{pH}=$ $12,[\mathrm{Mg}(\mathrm{II})]$ values indicated on the curve in the graph) Spectra began to be taken about 30 minutes after the last reagent was added, this process continued to be more concentrated later.

Table 4. Optimum values of critical factors in the measurement medium

\begin{tabular}{|l|c|c|c|c|c|}
\hline Parametre & $\mathrm{pH}$ & $\begin{array}{c}\text { SDS, } \\
\% \\
(\mathrm{w} / \mathrm{v})\end{array}$ & $\begin{array}{c}\text { Oksin, } \\
\mathrm{mgL}^{-1}\end{array}$ & $\begin{array}{c}\lambda_{\max }, \\
\mathrm{nm}\end{array}$ & Time \\
\hline Value & 12 & 0,75 & 150 & 390 & $\begin{array}{c}20 \\
\mathrm{dak}^{*}\end{array}$ \\
\hline
\end{tabular}

* This is the time after which the last reagent is added and the moment of equalizing the levels is taken as the starting point.

\subsection{Interferences}

Species that have been investigated are generally found in the measurement environment. These are sodium, potassium, calcium, chloride, carbonate, bicarbonate, sulfate ions. No interference effects of sulfate, carbonate bicarbonate and nitrate were observed. Other results was given in Table 5. As the tolerance limit, the species/analyte $(\mathrm{w} / \mathrm{w})$ ratio or the corresponding concentration that changed the absorbance by $\pm 5 \%$ was accepted.

Observations up to $0.01 \mathrm{M}$ to determine whether $\mathrm{NaCl}$ is interfering. No interference was observed. Precipitation was observed when $\mathrm{KCl}$ was $50 \mathrm{mgL}^{-1}$ in the measuring medium. Observation of this turbidity even in the blank solution indicates that the turbidity is due to the cloud point state or peptidization or coagulation; it can also be said that $\mathrm{KCl}$ interference is 
independent of $\mathrm{Mg}$ (II). The $\mathrm{KCl}$ value of $50 \mathrm{mgL}^{-1}$ corresponds to a concentration of $23.54 \mathrm{mgL}^{-1} \mathrm{~K}^{+}$if calculated. Considering that the concentration in the original sample is at least 10 -fold diluted to the final medium, the $\mathrm{K}^{+}$ion concentration in the original sample is at least $235 \mathrm{mgL}^{-1}$. This value is above the $\mathrm{K}^{+}$levels found in water and drug samples. As a result, it can be said that $\mathrm{K}^{+}$and $\mathrm{Na}^{+}$will not be at the level that will cause effect in the samples where the method is applied.

Since heavy metal ions can complex with oxin such as $\mathrm{Mg}$, interference is expected when these ions are present. The concentrations of metal ions other than $\mathrm{Ca}(\mathrm{II}), \mathrm{Mg}$ (II) in water and drug are at ppb levels. Moreover, the method is much lower than they are subjected to dilution when applied, so that their interference is out of the question.

When the $\mathrm{Ca} / \mathrm{Mg}$ ratio was above $2 / 1$, it was observed that the absorbance increase exceeded $\pm 5 \%$. This ratio was taken as the tolerance limit for Ca (II). Masking with tartrate, citrate and EDTA was used to remove Ca (II) interference, but none of them yielded a positive and consistent result.

Table 5. Tolerance limits of some species (which changes the absorbance by $\pm 5 \%$ ) species / analyte ratios), ( $\mathrm{ppm} / \mathrm{ppm})$

\begin{tabular}{|l|l|l|}
\hline Species & Tolerance limit & $\begin{array}{c}{[\mathrm{Sp}] /[\mathrm{Mg}]} \\
(\mathrm{ppm} / \mathrm{ppm})\end{array}$ \\
\hline $\mathrm{NaCl}$ & $\begin{array}{c}>0,01 \mathrm{M} \\
(>580 \mathrm{ppm})\end{array}$ & $>145$ \\
\hline $\mathrm{KCl}$ & $50 \mathrm{ppm}^{*}$ & $(\mathrm{Mg}$ independent $)$ \\
\hline $\mathrm{Ca}(\mathrm{II})$ & - & $2 / 1$ \\
\hline
\end{tabular}

*Coagulation limit
The parameters of a calibration curve obtained by taking the optimal values of each critical factor was given in Table 6.

Table 6. Calibration curve parameters (two repeat measurements for each concentration)

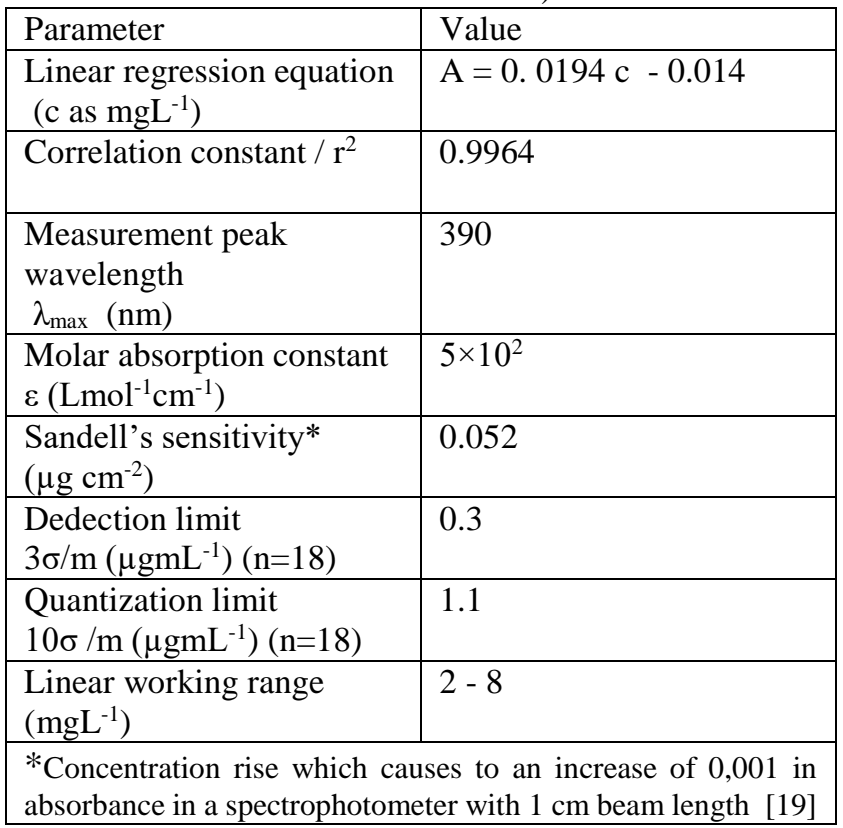

\subsection{Calibration curve parameters}

The accuracy and precision of the proposed method were tested by applying mineral water sample of two different brands and some $\mathrm{Mg}$ supplement drugs.

The composition of the mineral water sample is given on the packaging bottle. As these values were determined by the standard method in routine analysis sites, they were taken as the correct value or comparison value. The obtained data are given in Table 7.

\subsection{Calibration curve parameters}

Table 7. Application of the proposed method to some water samples

\begin{tabular}{|l|l|l|l|l|l|}
\hline Sample & $\begin{array}{l}\text { Known conc., } \\
\mathrm{mgL}^{-1}\end{array}$ & $\mathrm{Ca} / \mathrm{Mg}$ & $\begin{array}{c}\text { Found conc., } \\
\mathrm{mgL}^{-1}\end{array}$ & \% R & \% RSD \\
\hline $\begin{array}{l}\text { Mineral } \\
\text { samples 1 }\end{array}$ & $317^{\mathrm{b}}$ & $0.13^{\mathrm{c}}$ & $332.8 \pm 34.8^{\mathrm{a}}$ & 105 & 11 \\
\hline $\begin{array}{l}\text { Mineral } \\
\text { samples 2 }\end{array}$ & & & & & \\
\hline
\end{tabular}

a $\mathrm{n}=5, \% 90$ convedence level, $\mathrm{t}=2,13$,

${ }^{\mathrm{b}}$ The value given on the label.

${ }^{\mathrm{c}}$ Rate calculated from the values given on the packaging (w/w) 
Table 8. Application of the proposed method to some drug samples and testing the accuracy by analyte spiked method

\begin{tabular}{|l|l|l|l|l|}
\hline Sample & $\begin{array}{l}\text { Added Con., } \\
\mathrm{mgL}^{-1}\end{array}$ & $\begin{array}{l}\text { Conc. difference } \\
\text { found, } \mathrm{mgL}^{-1}\end{array}$ & $\% \mathrm{R}$ & $\%$ RSD \\
\hline \multirow{5}{*}{ Mg-sulfat ampoule* } & 0 & $0.97 \pm 0.49$ & - & 11 \\
\cline { 2 - 5 } & 2 & $1.34 \pm 0.00$ & 67 & 0 \\
\cline { 2 - 5 } & 4 & $4.22 \pm 0.16$ & 106 & 0,9 \\
\cline { 2 - 5 } & 6 & $5.98 \pm 6.18$ & 100 & 23 \\
\hline Magnezya Calsinee & 0 & $2.54 \pm 0.54$ & - & 13 \\
\cline { 2 - 5 } & 2 & $1.86 \pm 0.43$ & 93 & 14 \\
\cline { 2 - 5 } & 4 & $3.92 \pm 0.71$ & 98 & 7 \\
\cline { 2 - 5 } & 6 & $5.05 \pm 0.59$ & 84 & 20 \\
\hline Magosit & 0 & $2.03 \pm 1.62$ & - & 19 \\
\cline { 2 - 5 } & 2 & $1.86 \pm 1.59$ & 93 & 7 \\
\cline { 2 - 5 } & 4 & $4.64 \pm 1.46$ & 116 & 0,6 \\
\cline { 2 - 5 } & 6 & $5.88 \pm 0.16$ & 98 & 6 \\
\hline \multirow{5}{*}{ Magvital } & 0 & $0.58 \pm 1.63$ & - & 106 \\
\hline
\end{tabular}

${ }^{*} \mathrm{n}=2, \% 90$ convedence level, $\mathrm{t}=6,31, \bar{x}:$ Mean volues

** $\mathrm{n}=3, \% 90$ güven düzeyi, $\mathrm{t}=2,92$

The analyte spiked method or standard addition / method was used to determine the accuracy for the drugs. For this, the following path was followed. Equal amounts $(200 \mu \mathrm{L})$ of the prepared sample solution were added to each of a series of $10 \mathrm{~mL}$ each flask. On top of that, $0-600 \mu \mathrm{L}$ of $100 \mathrm{ppm} \mathrm{Mg}$ (II) standard was added for each volume to be measured again. Other procedures were performed according to Section 2.3. The obtained data are given in Table 8 .

When the method was applied to water samples, accuracy was positive with 5\% recovery in Kizılay Erzincan mineral water sample while accuracy was lower with $126 \%$ recovery in Beypazarı mineral water sample (Table 7). This is due to the $\mathrm{Ca} / \mathrm{Mg}$ ratio of 0.13 / 1 Kizlay Erzincan mineral water Ca (II) is not interference. The other is the Beypazarı mineral water with a $\mathrm{Ca} / \mathrm{Mg}$ ratio of $2.2 / 1$, which is above the tolerance limit. The error rate in this example is therefore higher than the previous water sample.

Accuracy values as percent recovery are mostly positive when the method is applied to magnesium supplementation drugs that do not contain $\mathrm{Ca}$ (II) according to the propectus information. The repeatability values are unfortunately not the same (Table 8).

\section{Conclusions}

As a result, the applicability of this method is limited by $\mathrm{Ca}$ (II) interference. The method can be applied to magnesium-supplementing drugs which do not contain $\mathrm{Ca}$ (II). When applied to water samples, it may give error results due to $\mathrm{Ca}$ (II) interference.

\section{Conflicts of interest}

The authors state that did not have conflict of interests

\section{References}

[1] Pramaura, E. and Pelizetti, E., Surfactants in Analytical chemistry, Chapter 4, Hardbound, 2008; pp 203-211.

[2] Young A., Sweet T. R. and Baker B. B. Simultaneous Spectrophotometric Determination of Calcium and Magnesium, Analytical Chemistry, 27(3) (1955) 356-359.

[3] Ferguson J. W., Richard J. J., O'laughlin J. W. and Banks C. V. Simultaneous Spectrophotometric Determination of Calcium and Magnesium with Chlorophosphonazo III, Analytical Chemistry, 36 (4) (1964) 796-799.

[4] Shibata S. Uchiumi, A., Saski S. and Goto K. Spectrophotometric determination of magnesium with chromotrope 2R: Application to zinc and aluminum alloys, Analytica Chimica Acta, 44 (2) (1969) 345-352.

[5] Lurie, J., Handbook of Analytical Chemistry, MIR publishers, Moskow: (1975); pp 261 - 326,

[6] Khayam-Bashi H., Liu TZ. and Walter V. Measurement of Serum Magnesium with a Centrufigal Analyzer, Clin. Nephrol., 46 (1977) 326-331.

[7] Ceba M., R., Fernándezgutiérrez A. and Mahedero M. C. 1,8-dihydroxyanthraquinone- $\mathrm{Mg}$ 
complex: II. Spectrophotometric study, Determination of $\mathrm{Mg}(\mathrm{II}), \quad$ Microchemical Journal, 27 (1982) 339-344.

[8] Xing Q. and Ying Z. Rapid analysis of cationexchangeable property in acidic soil: III. Sensitive spectrophotometric determination of microgram amounts of exchangeable magnesium with xylidyl Blue $I$ in the presence of CTAB, Microchemical Journal, (33) (3) (1986) 364-370.

[9] Peerzeda N. and Kozlik E., Spectrophotometric Determination of Magnesium with 2,2',6',2" Terpyridine, Analytical Letters, (1990) 1087 - 1093.

[10] Idriss K. A., Sedaira H. and Ahmed H. M. An Insight into the Solution Equilibria of Magnesium (II) with Purpurin and Spectrophotometric Determination of Magnesium, Talanta, 54(2) (2001) 369-375.

[11] Tesfaldet Z. O., Staden J. F. and Stefan R. I. Spectrophotometric determination of magnesium in pharmaceutical preparations by cost-effective sequential injection Analysis, Talanta, (64) (2004) 981-988

[12] Fangqin C., Yaning Z., Huimin C. and Chuan D. UV spectrophotometric determination of magnesium and calcium in brine from salt lake, Inorganic Chemicals Industry, 13 (2006) 11-21.

[13] Afkhami A., Madrakian T. and Abbasi M. T. Simultaneous determination of calcium, magnesium and zinc in different foodstuffs and pharmaceutical samples with continuous wavelet transforms, Food Chemistry, (109) (3) (2008) 660669.

[14] Dallali N. and Agrawal Y. K. Solvent Extraction and Spectrophotometric Determination of Magnesium by Paratoly 1-2-Thenohydroxamic Acid and Quinalizarin, Iran. J. Chem. \& Chem. Eng., (23) (1) (2004) 65-71.

[15] Abernethy M. and Fowler R. T., Micellar Imrovement of the Calmatige Compleximetric Measurement of Magnesium in Plasma, Clin. Chem., 28 (3) (1982) 520-522

[16] Ratge D., Koshe K. and Wisser H. Measurement of Magnesium in Serum and Urine with a Random Access Analyzer by Use of a Modified Xylidyl blue-1 Procedure, Clin Chim Acta., 159 (1986) 197-203.

[17] Benamor M. ve Aguerssif N., Simultaneous determination of calcium and magnesium by derivative spectrophotometry in pharmaceutical products, Spectrochimica Acta Part A, (69) (2008) 676-681.

[18] Gürkan R., Ulusoy H. I. and Akçay M. MicellarSensitized Spectrophotometric Determination of Magnesium in Drinking Water, Eurasian J. Anal. Chem., (4) (2) (2009) 127-140.

19] Bode H., On Sandell's sensitivity, Fresenius J Anal. Chem., 339:898 (1991) 12-15. 